\title{
KOMODIFIKASI, SPASIALISASI, DAN STRUKTURASI DALAM MEDIA BARU DI INDONESIA (Ekonomi Politik Komunikasi Vincent Mosco Pada Line Webtoon)
}

\author{
Zera Edenzwo Subandi ${ }^{1)}$ dan Teguh Priyo Sadono ${ }^{2)}$ \\ ${ }^{1)}$ MagisterIlmu Komunikasi, Universitas Bunda Mulia, zsubandi@bundamulia.ac.id \\ ${ }^{2)}$ Magister Ilmu Komunikasi, Universitas Bunda Mulia, tsadono@bundamulia.ac.id
}

\begin{abstract}
ABSTRAK
Kemunculan LINE Webtoon di Indonesia menawarkan dinamika media baru yang sangat menarik untuk diteliti dalam kajian ekonomi politik Vincent Mosco. Dalam teorinya, Vincent Mosco menyinggung tentang globalisasi ekonomi politik media hari ini yang menjelaskan adanya transisi media lama dan kemunculan media baru. Tujuan penelitian ini untuk melihat dan mengkritisi praktik ekonomi politik komunikasi Vincent Mosco mulai dari Komodifikasi, Spasialisasi, hingga Strukturasi yang berkaitan dengan proses kontrol LINE Webtoon atas isi, audiens, dan pekerja serta penyebarannya di Indonesia dan penguasaan pasar di Indonesia.Penelitian ini menggunakan pendekatan kualitatif dengan metode studi kasus. Jenis penelitian adalah eksploratif yang didasarkan pada tradisi kritis dan paradigma kritis. Penelitian ini menggunakan teori Ekonomi Politik Komunikasi Vincent Mosco. Data primer penelitian merupakan hasil observasi dan wawancara, sedangkan data sekunder penelitian merupakan hasil dokumentasi. Hasil penelitian ini menyatakan bahwa Komodifikasi dalam LINE Webtoon terdiri atas komodifikasi konten, komodifikasi audiens, dan komodifikasi pekerja. Komodifikasi konten menunjukkan bahwa audiens turut serta dalam menentukan isi atau kontennya, lalu adanya ketidak jelasan batasan dari syarat konten tidak layak pada LINE Webtoon, sehingga Peneliti menemukan beberapa konten yang termasuk dalam kategori tidak layak. Komodifikasi audiens menunjukkan bahwa pembaca di Indonesia merupakan pembaca LINE Webtoon yang terbanyak, sehingga menjadi pasar yang sangat potensial untuk diperdagangkan pada pengiklan. Komodifikasi Pekerja terlihat pada kreator yang berkarya di Webtoon Challenge namun tidak mendapatkan bayaran sama sekali. Jika mereka ingin mendapatkan uang, mereka bisa ikut lomba Rising Star, namun kriteria yang diberikan sangat sulit. Walau pun menang, belum tentu menjadi akun official. Akun official pun mendapatkan tanggung jawab yang cukup tinggi mulai dari konten yang harus sesuai dengan minat pasar, deadline setiap minggu, dan minimal panel dalam setiap episodenya. Segala biaya proses produksi hingga penerbitan ditanggung oleh kreator. Kreator hanya mendapatkan gaji bulanan dari LINE Webtoon. Kreator dibuat seakan LINE Webtoon menyediakan ruang untuk berkarya, namun Peneliti lihat ini sebagai usaha LINE Webtoon mengubah nilai guna keahlian serta karya kreator menjadi nilai jual. Terdapat webtoon yang berjudul "Seventeen" yang berisikan potongan adegan-adegan dalam webdrama yang diproduksi oleh NAVER TV. Akun tersebut tidak melalui tahap Webtoon Challenge dan langsung terbit di Indonesia. Adanya promosi serial dari webdramayang sengaja dilakukan karena NAVER Corporation memiliki kekuasaan untuk itu.Spasialisasi yang tertangkap pada penelitian ini dalam proses penyebaran LINE Webtoon adalah berkaitan
\end{abstract}


dengan penyebaran LINE Webtoon di Indonesia menyangkut perihal konten yang tidak layak dan perluasan jaringan bisnis dari NAVER CORP yang memasukkan webdrama "Seventeen" ke dalam LINE Webtoon Indonesia. Hal tersebut juga berkaitan dengan ketidakadilan bagi kreator Indonesia yang berjuang sejak awal. Yang menjadi permasalahan utama, peneliti mendapatkan hasil bahwa karena belum adanya peraturan Pemerintah yang mengatur tentang penerbitan komik online, penyebarannya jadi belum bisa dipagari. Siapa saja bisa akses dengan mudah melalui website atau aplikasi, termasuk mengakses webtoon yang berisikan adegan dewasa. Strukturasi dalam LINE Webtoon adalah LINE Webtoon merupakan pionir komik online pertama di Indonesia yang memiliki pembaca terbanyak. LINE Webtoon seakan sebagai hegemoni Jepang dan Korea atas Indonesia. Jepang dan Korea bekerja sama untuk menjual produk yang benar-benar laku di pasar Indonesia. Namun, Pemerintah harus benar-benar bisa mengontrol pergerakkan ini agar tidak membawa dampak negatif bagi kebudayaan dan moral Bangsa Indonesia.

\section{Kata Kunci:Vincent Mosco, Kualitatif, Studi kasus.}

\section{ABSTRACT}

The emergence of LINE Webtoon in Indonesia offers a very interesting new media dynamics to be studied in Vincent Mosco's political economy study. In his theory, Vincent Mosco alludes to the globalization of the political economy of today's media explaining the transition of old media and the emergence of new media. The purpose of this study is to examine and criticize the political economy communications practices of Vincent Mosco from Commodification, Spatialization, to Structures related to the Line Webtoon control process for content, audience and workers and its distribution in Indonesia and market share in Indonesia.This research uses qualitative approach with case study method. This type of research is explorative which is based on critical tradition and critical paradigm. This research uses Political Economy Communication theory Vincent Mosco. Primary data of research is result of observation and interview, while secondary data of research is result of documentation. The results of this study suggest that Commodification in LINE Webtoon consists of commodification of content, commodification of audience, and commodification of workers. The content commodity indicates that the audience is participating in the content, and there is a lack of clarity on the terms of inappropriate content on the LINEWebtoon, so the Researcher finds some of the content falling into inappropriate categories. Audiences' commodity shows that readers in Indonesia are the largest LINE Webtoon readers, making it a very potential market for traders to advertisers. Workers' Commodities are seen on creators working on the Webtoon Challenge but are not getting paid at all. If they want to earn money, they can join the Rising Star contest, but the criteria given is very difficult. Although winning, not necessarily an official account. The official account also gets quite high responsibilities ranging from content to match market interests, deadlines every week, and minimal panels in each episode. All costs of the production process until the publishing is borne by the creator. Creators get only a monthly salary from LINE Webtoon. Creators are created as LINE Webtoon provides space for work, but Researchers refer to this as LINE Webtoon's efforts to change the value of expertise and creativity into selling points. There is a webtoon entitled "Seventeen" which contains 
snippets of scenes in webdrama produced by NAVER TV. The account does not go through the Webtoon Challenge stage and is published in Indonesia. The existence of a serial promotion from webdrama that deliberately done because NAVER Corporation has the power to it.The spatialization caught in this research in the LINE Webtoon deployment process is related to the deployment of LINE Webtoon in Indonesia regarding the subject of inappropriate content and the expansion of the business network of the NAVER CORP that incorporates the "Seventeen" webdrama into LINE Webtoon Indonesia. It is also related to the injustice to Indonesian creators who fought from the beginning. The main problem, the researchers get the result that because there is no government regulation governing the publishing of online comics, the spread so can not be fenced. Anyone can easily access through websites or apps, including accessing a webtoon that contains adult scenes. Structure in LINE Webtoon is LINE Webtoon is the first online comic pioneer in Indonesia that has the most readers. LINE Webtoon as Japan and Korea hegemony over Indonesia. Japan and Korea work together to sell products that really sell well in the Indonesian market. However, the Government should really be able to control this movement so as not to bring negative impacts to the culture and moral of the Indonesian Nation.

Keywords: Vincent Mosco, Qualitative, Case study.

\section{PENDAHULUAN}

\section{Latar Belakang Penelitian}

LINE Webtoonhadir sebagai salah satu bentuk media baru di Indonesia. LINE Webtoon dalam tiga tahun terakhir, sejak 2015, telah menjadi salah satu bisnis yang sangat menguntungkan pada masa kini dan menjadi bagian dalam politik ekonomi komunikasi. LINE Webtoon dapat menembus hingga angka 6.000 .000 pembaca aktif tiap bulannya berdasarkan hasil survey yang diperoleh per tahun 2016-2017. Masyarakat lebih mengutamakan kemudahan untuk mengakses segala informasi. Masyarakat pada beberapa periode lalu jika ingin membaca berita mereka harus membeli koran, mencari ilmu dengan membaca buku, membaca cerita mereka membeli novel atau komik, kemudian menonton berita harus melalui televisi, mendengarkan radio harus melalui perangkat radio, dan lainnya. Semua sudah sangat mudah diakses saat ini dengan kemunculan media baru atau biasa yang kita kenal dengan internet.

Masyarakat sangat dipermudah dengan adanya kemunculan internet. Masyarakat dengan mudahnya bisa mengakses portal berita online, membaca melalui e-book, novel dan komik online, streaming acara tv dan radio dimana saja, dan lainnya. Hal ini membuat perubahan pada pola konsumsi masyarakat yang mulai meninggalkan media lama dan beralih pada media baru. Media baru menjadi cerminan pola konsumsi masyarakat zaman ini yang ingin mengakses informasi atau konten atau isi suatu media secara efektif dan efisien.

Masyarakat jadi dengan mudah mengakses informasi pada media baru di mana pun dan kapan pun tanpa terbatas ruang dan waktu. Informasi yang tersebar dibelahan dunia mana pun bahkan juga dapat diakses dengan mudah. Salah satunya adalah LINE Webtoon. LINE Webtoon adalah komik online yang merupakan salah satu bentuk dari media baru yang berasal dari Korea. Penurunan jumlah penjualan komik konvensional 
National Conference of Creative Industry:

Sustainable Tourism Industry for Economic Development

Universitas Bunda Mulia, Jakarta, 5-6 September 2018

ISSN No: 2622-7436

dalam bentuk cetakkan menjadi masalah utama yang dihadapi Korea Selatan pada tahun 2004. Kim Jun Koo merupakan pencetus Webtoon yang saat itu sebagai jalan keluar penurunan penjualan komik cetak di Korea Selatan. Webtoon bisa dibilang sebagai bentuk atau platform yang baru untuk menghubungkan kreator komik dan pembaca komik. Hal tersebut juga dipraktikkan di Indonesia.

Webtoon yang berada dalam naungan LINE Corporation masuk ke Indonesia sejak tahun 2014, dengan menawarkan platform baru untuk membaca komik secara online. Indonesia sendiri menjadi pasar yang sangat menjanjikan bagi LINE Webtoon. LINE Webtoon merupakan pionir komik online pertama di Indonesia sejak tahun 2015, fakta tersebut menjadikan penelitian ini memiliki keunikkan tersendiri. LINE Webtoon selain membangkitkan "mati suri" para pembaca komik di Korea Selatan, ternyata kehadiran LINE Webtoon juga memberikan kesempatan serta kemudahan bagi para kreator dan pembaca komik di Indonesia.

LINE Webtoon sebagai institusi dan industri yang memiliki karakter sebagai kajian ekonomi politik komunikasi. Peneliti melihat adanya proses kontrol atas isi, audiens dan pekerja yang diberlakukan. Peneliti melihat bahwa ada beberapa judul dari genre romantis dan drama yang memunculkan gambar-gambar yang bersifat cabul dan tidak sesuai dengan nilai budaya yang dianut di Indonesia, padahal aturan mengenai gambar cabul tersebut juga sudah dijabarkan dalam syarat dan ketentuan yang diberlakukan oleh LINE Webtoon. Alur cerita yang dibuat para kreator bisa berasal dari imajinasi sendiri dan pengaruh dari pihak luar, termasuk pembaca dan editor. Pembaca juga dijadikan sebagai alat tukar kepada pengiklan. LINE Webtoon yang masih memiliki hubungan dengan NAVER Webdrama bahkan memasukkan webdrama yang berjudul "Seventeen" ke dalam LINE Webtoon Indonesia dan menjadi satu-satunya webtoon yang berformat cuplikan adegan para aktor dan aktris. Webtoon "Seventeen" bahkan menjadi akun official yang terbit tanpa melalui tahap Webtoon Challenge. Hal ini tentu sangat merugikan para kreator yang bisa dibilang sebagai pekerja LINE Webtoon. Para kreator yang baru menerbitkan webtoon, bisa masuk ke dalam kategori Webtoon Challenge, di mana mereka dapat menerbitkan webtoon tanpa mendapatkan upah sedikit pun. Setelah melalui beberapa proses, mereka bisa masuk ke dalam nominasi Rising Star dan akan mendapatkan hadiah uang tunai sebesar Rp 5.000.000,-. Apabila sudah menjadi pemenang Rising Star, mereka tidak akan otomatis menjadi Official Account. Kreator yang menjadi Official Account akan dipilih langsung oleh pihak LINE Webtoon. Setelah menjadi Official Account, baru mereka akan dibayar oleh pihak LINE Webtoon dengan sistem mendapatkan gaji.

Kemunculan LINE Webtoon di Indonesia menawarkan dinamika media baru yang sangat menarik untuk diteliti dalam kajian politik ekonomi Vincent Mosco. Vincent Mosco dalam teorinya menyinggung tentang globalisasi politik ekonomi media hari ini yang menjelaskan adanya transisi media lama dan kemunculan media baru. LINE Webtoon yang merupakan gabungan inovasi teknologi komunikasi dari Negara Jepang dan Korea, masuk ke Indonesia dengan dikemas sedemikian rupa dari bentuk medianya, informasi (dalam hal ini cerita pada komik), minat pembaca, serta para kreator komik menjadi satu paket yang dapat menjadi produk untuk dijual di pasar Indonesia dan bahkan manca negara.

Berdasarkan latar belakang di atas, Peneliti ingin melakukan penelitian lebih mendalam mengenai politik ekonomi media zaman ini yang berhubungan dengan media baru, LINE Webtoon. Peneliti menjadi tertarik untuk melakukan penelitian mengenai 


\section{"Komodifikasi, Spasialisasi, dan Strukturasi Dalam Media Baru di Indonesia (Ekonomi Politik Komunikasi Vincent Mosco PadaLINE Webtoon)".}

\section{Fokus Penelitian dan Pertanyaan Penelitian}

Masalah adalah lebih dari sekedar pertanyaan, dan jelas berbeda dengan tujuan. Masalah dalam penelitian kualitatif bertumpu pada suatu fokus. ${ }^{1}$ Peneliti akan menjabarkan pembatasan masalah yang akan dibahas untuk memberikan garis batas secara jelas mengenai fokus penelitian. Komodifikasi, spasialisasi, dan strukturasi dalam komik berbasis online, LINE Webtoon, menjadi masalah penelitian yang akan dibahas dalam penelitian ini.

Pada bagian komodifikasi, peneliti akan membahas secara eksploratif mengenai komodifikasi yang didalamnya terdapat pembahasan tentang komodifikasi isi, komodifikasi audiens, dan komodifikasi pekerja. Sedangkan pada bagian spasialisasi, peneliti akan membahas tentang bagaimana proses pendistribusian LINE Webtoon sehingga bisa mengatasi permasalahan komunikasi mengenai jarak atau ruang dan waktu. Pada bagian akhir tentang strukturasi, peneliti akan membahas mengenai kelas, gender, ras, pergerakkan sosial, dan hegemoni yang peneliti curigai bahwa sebenarnya ada sesuatu yang dimaksudkan oleh kekuatan dominan dengan masuknya LINE Webtoon ke Indonesia. Berdasarkan penjabaran di atas, maka dirumuskan permasalahan penelitian sebagai berikut :

1. Bagaimana permasalahan konten, pemanfaatan pembaca serta pemanfaatan pekerja yang berkaitan dengan komodifikasi isi, komodifikasi audiens dan komodifikasi pekerja dalam LINE Webtoon?

2. Bagaimana permasalahan penyebaran konten tersebut yang berkaitan dengan spasialisasi dalam proses penyebaran LINE Webtoon?

3. Mengapa LINE Webtoon bisa menguasai pasar di Indonesia berkaitan dengan penampakkan strukturasi yang dibuat oleh LINE Webtoon?

\section{Tujuan Penelitian}

1. Mengungkapkan secara eksplorasi perihalkomodifikasi isi, audiens, dan pekerja dalam LINE Webtoon.

2. Mengungkapkan secara eksplorasi perihal spasialisasi dalam proses penyebaran LINE Webtoon.

3. Mengungkapkan secara eksplorasi penampakkan strukturasi yang dibuat oleh LINE Webtoon.

\footnotetext{
${ }^{1}$ Lexy J., Moleong, Metodologi Penelitian Kualitatif, (Bandung: PT Remaja Rosdakarya, 2010) hlm. 93.
} 
National Conference of Creative Industry: Sustainable Tourism Industry for Economic Development Universitas Bunda Mulia, Jakarta, 5-6 September 2018

ISSN No: 2622-7436

\section{TINJAUAN PUSTAKA}

Tabel 1.Penelitian terdahulu (state of the art)

\begin{tabular}{|c|c|c|}
\hline No & Nama dan Judul & Keterangan \\
\hline 1 & $\begin{array}{l}\text { "Politik Ekonomi Vincent Moscow } \\
\text { oleh Media Online Entertainment } \\
\text { Kapanlagi.com"TM" } \\
\text { Jurnal oleh: Indah Wenerda, S.Sn., } \\
\text { M.A (2015) }\end{array}$ & $\begin{array}{l}\text { Paradigma: Kritis } \\
\text { Pendekatan: Kualitatif } \\
\text { Objek Penelitian: Komodifikasi, } \\
\text { Spasialisasi dan Strukturasi pada } \\
\text { Media Online KapanLagi.com }\end{array}$ \\
\hline 2 & $\begin{array}{l}\text { "Spasialisasi dan Strukturasi Dalam } \\
\text { Sistem Siaran Jaringan di Indonesia } \\
\text { (Studi Kasus pada Kompas TV)" } \\
\text { Thesis oleh: Gilang Gusti Aji } \\
(1206190412)(2014)\end{array}$ & $\begin{array}{l}\text { Paradigma: Kritis } \\
\text { Pendekatan: Kualitatif Deskriptif } \\
\text { Objek Penelitian: Spasialisasi dan } \\
\text { Strukturasi pada Kompas TV. }\end{array}$ \\
\hline 3 & $\begin{array}{l}\text { "Spasialisasi Dalam Politik Ekonomi } \\
\text { Komunikasi (Studi Kasus MRA } \\
\text { Media)" } \\
\text { Jurnal oleh:Isma Adila (2011) }\end{array}$ & $\begin{array}{l}\text { Paradigma: Kritis } \\
\text { Pendekatan: Kulitatif } \\
\text { Objek Penelitian: Spasialisasi } \\
\text { pada MRA Media }\end{array}$ \\
\hline 4 & $\begin{array}{l}\text { "Perbandingan Pendekatan Ekonomi } \\
\text { Politik Media dan Studi Kebudayaan } \\
\text { dalam Kajian Komunikasi Massa" } \\
\text { Jurnal oleh:S. Sarwoprasodjo-Agung } \\
\text { (2008) }\end{array}$ & $\begin{array}{l}\text { Paradigma: Kritis } \\
\text { Pendekatan: Multiperspektif } \\
\text { Objek Penelitian: Makna, Pesan } \\
\text { dan Efek Kajian Komunikasi } \\
\text { Massa dalam pendekatan ekonomi } \\
\text { politik dan studi kebudaayaan }\end{array}$ \\
\hline 5 & $\begin{array}{l}\text { "Ekonomi Politik Media Penyiaran } \\
\text { (Televisi): Komodifikasi Tayangan } \\
\text { Kriminalitas TKP TV 7" } \\
\text { Thesis oleh: Bernadetta Yovita L.S. } \\
(690311007 \mathrm{X})(2015)\end{array}$ & $\begin{array}{l}\text { Paradigma: Kritis } \\
\text { Pendekatan: Kualitatif Deskriptif } \\
\text { Objek Penelitian: Komodifikasi } \\
\text { pada tayangan TV } 7\end{array}$ \\
\hline
\end{tabular}

Sumber : Penelitian sebelumnya

Peneliti tidak menemukan persamaan total pada penelitian sebelumnya dengan penelitian yang akan dilakukan oleh peneliti saat ini. Terdapat perbedaan baik dari segi sifat dan objek penelitian. Peneliti menggunakan tradisi kritis sebagai tradisi penelitian. Peneliti melihat dari keempat kategori dalam tradisi kritis, penelitian yang dilakukan oleh peneliti masuk ke dalam kategori Postmodernisme. Penelitian ini menggunakan pendekatan kualitatif yang bersifat eksploratif. Objek dari penelitian ini adalah komodifikasi, spasialisasi dan strukturasi pada media baru, LINE Webtoon, yang merupakan pionir komik berbasis online pertama dan terbesar di Indonesia sejak tahun 2014. Pembahasan di atas akan dijabarkan lebih jelas pada penelitian ini.

\section{Teori Ekonomi Politik Komunikasi Vincent Mosco}

Penelitian ini menggunakan teori Ekonomi Politik Komunikasi Vincent Mosco. Politik ekonomi merupakan studi yang membahas tentang relasi sosial, khususnya hubungan kekuasaan, yang saling berkaitan dari proses produksi, distribusi, dan konsumsi sumber daya, termasuk sumber daya komunikasi. Politik ekonomi juga 
membahas tentang nilai tukar antara fungsi dan kegunaan. Politik ekonomi komunikasi dijadikan sebagai bisnis media.

Di mana dulu, perusahaan, termasuk mereka dalam industri komunikasi, berbasis di satu negara dan bergerak di dunia sebagai kekuatan eksternal, hari ini mereka semakin terintegrasi ke dalam jalinan masyarakat ke titik di mana seringkali sulit untuk menentukan negara asal atau kebangsaan mereka. Beroperasi sebagai pemilik, mitra, dan dalam aliansi strategis dengan perusahaan yang berbasis di negara tuan rumah, mereka telah menyebabkan ekonom politik bergeser dari berbicara tentang kekuatan perusahaan multinasional untuk mengatasi kebangkitan ekonomi transnasional di seluruh dunia.

Menurut Vincent Mosco, suatu korporasi yang bergerak dalam industri komunikasi dapat tersebar luas ke manca negara dengan adanya kekuasaan dan kekuatan dan menguasai pangsa pasar di negara tersebut. Terjalinnya kerjasama antara korporasi luar negeri dengan pihak pemerintah, swasta, investor, serta pemangku kepentingan dalam negeri lainnya dalam industri komunikasi. Secara tidak sadar, masyarakat pada negara tersebut mengalami bias dan mempercayai bahwa suatu produk adalah berasal dari negaranya, padahal itu adalah produk luar negeri. Namun, selama produk yang ditawarkan dapat memuaskan kebutuhan konsumsi akan industri komunikasi masyarakat, maka produk tersebut akan laku di pasaran. Dampaknya akan terjadi perubahan sosial atau transisi atas industri komunikasi seperti perubahan khalayakan media lama menjadi media baru.

Politik ekonomi komunikasi melihat komunikasi sebagai keseluruhan proses ekonomi, politik, sosial dan budaya yang fundamental atau yang mendasar dalam masyarakat. Oleh karena itu, sangat penting untuk memikirkan praktik komunikasi dalam kehidupan sehari-hari, termasuk komunikator dan alat yang mereka gunakan dalam kontruksi sosial dan budaya. Komunikasi bukan hanya transmisi informasi, namun juga merupakan kontruksi sosial melalui percakapan, media cetak, penyiaran, alat telekomunikasi, dan internet. Dalam bukunya, Mosco menulis bahwa yang terpenting dalam politik ekonomi bukan hanya tentang kerjasama dalam jaringan, namun juga tentang kekuasaan dan hierarki baik secara vertikal maupun horizontal yang akan dibahas jelas pada sub bab spasialisme.

Politik ekonomi dan komunikasi secara bersama-sama terbentuk dari praktikpraktik pertukaran sosial dan budaya, dimulai dengan mendefinisikankomunikasi sebagai proses pertukaran sosial yang hasilnya adalah ukuran atau tanda hubungan sosial dan kebiasaan yang dilakukan terus menerus menjadi budaya melalui berbagai bentuk mulai dari media cetak hingga media baru yang berbasis online.

Teori politik ekonomi Vincent Mosco membahas mengenai tiga proses yaitu komodifikasi, spasialisasi, dan strukturasi. Komodifikasi dibagi menjadi tiga, yaitu komodifikasi isi yang berhubungan dengan konten dari media yang akan disebarluaskan ke audiens, komodifikasi audiens yang berhubungan dengan rating guna kepentingan pengiklan, dan komodifikasi pekerja yang berhubungan dengan bagaimana pekerja dimanfaatkan oleh pemangku kepentingan media. Spasialisasi membahas tentang penyebaran produk oleh media kepada audiens atau khalayak tanpa terhalang oleh ruang dan waktu dengan memanfaatkan kemajuan teknologi komunikasi. Hal ini berkaitan dengan bentuk atau jenis teknologi yang digunakan, jaringan, hingga kecepatan distribusi dengan berbagai cara, hingga integrasi yang dimiliki oleh perusahan baik secara vertikal atau pun horizontal. Spasialisasi horizontal adalah konsentrasi yang 
menyatukan industri media dengan cara memperluas produksi dan sumber daya media dengan cara membeli saham atau mengakuisisi media lain yang sama jenisnya dan setara. Spasialisasi vertikal adalah konsentrasi yang menggambarkan konsentrasi perusahaan-perusahaan dalam suatu lini bisnis yang memperluas kendali perusahaan atas proses produksi. Spasialisasi dilakukan untuk memperluas jangkauan media kepada khalayak luas. Spasialisasi vertikal dapat terjadi antar negara, di mana salah satu perusahaan sebagai perusahaan induk dan satu lagi sebagai anak perusahaan. Salah satu dampak dari proses spasialisasi adalah akan terjadi monopoli media komunikasi.

Strukturasi membahas tentang agen sebagai pembentuk suatu struktur dan struktur membentuk agen, sehingga menimbulkan terjadinya proses produksi dan reproduksi yang saling mempengaruhi satu dengan yang lainnya. Di dalamnya terjadi proses sosial antar agen untuk saling menukarkan idenya. Terjadi interaksi antara struktur dan agen sosial yang dinamis dan saling mempengaruhi antara satu sama lain. Dalam teori politik ekonomi komunikasi Vincent Mosco, proses stukturasi dapat menimbulkan adanya tindakan dan perubahan sosial yang dipengaruhi oleh struktur sosial seperti kelas, gender, ras, gerakkan sosial dan hegemoni. Strukturasi politik ekonomi komunikasi berkaitan dengan gerakkan sosial yang ada di masyarakat. Gerakkan sosial saat ini tidak lagi dibatasi dengan pergerakkan nyata, namun juga bisa dengan dukungan atau partisipasi secara online melalui media berjaringan internet. Strukturasi menciptakan hegemoni sebagai cara pandang dunia yang diterima begitu saja. Mosco menggunakan teori strukturasi Giddens untuk melihat bagaimana interaksi antara agen dan struktur dalam industri media komunikasi yang saling mempengaruhi dan mengikat.

\section{METODE PENELITIAN}

Penelitian ini menggunakan pendekatan kualitatif dengan metode studi kasus. Jenis penelitian adalah eksploratif yang didasarkan pada tradisi kritis dan paradigma kritis. Data primer penelitian merupakan hasil observasi dan wawancara, sedangkan data sekunder penelitian merupakan hasil dokumentasi.

\section{HASIL PENELITIAN DAN PEMBAHASAN}

Pada tahun 2004, Korea Selatan mengalami keterpurukkan dalam industri komik cetak karena pembaca lebih memilih membaca komik secara ilegal. Hal ini memicu kemunduran industri komik cetak di Korea dan membuat banyak penerbit gulung tikar. Akhirnya, Kim Jun Koo membuat sebuah situs komik daring (dalam jaringan) atau komik online yang disebut Webtoon pada tahun 2005.

LINE dirancang sebagai layanan pesan bergerak tak lama setelah gempa besar yang menghancurkan Jepang pada 11 Maret 2011. Setelah tragedi itu, menjadi jelas bahwa ada kebutuhan mendasar untuk alat komunikasi global yang dapat memperkuat hubungan manusia. Hanya beberapa bulan kemudian di bulan Juni, LINE Corporation meluncurkan aplikasi perpesanan bernama LINE. Dengan pendekatan ini, LINE telah tumbuh menjadi platform sosial dengan ratusan juta khalayak di seluruh dunia, memiliki fokus yang sangat kuat di benua Asia yang berkembang pesat. 
National Conference of Creative Industry:

Sustainable Tourism Industry for Economic Development

Universitas Bunda Mulia, Jakarta, 5-6 September 2018

ISSN No: 2622-7436

Pada tahun 2014, Naver Corporation bekerja sama dengan LINE Corporation dalam penyebaran Webtoon secara global dan terciptalah LINE Webtoon. Dengan demikian, Naver Webtoon menjadi anak perusahaan dari LINE Corporation. Di Indonesia, sejak April 2015 masuk platform baru yang dapat dinikmati oleh pada kreator dan pembaca komik online. LINE Webtoon menjadi pelopor aplikasi komik online dalam era new media di Indonesia. Melalui LINE Webtoon, kreator Indonesia mendapatkan kemudahan dalam menyebarkan karyanya pada aplikasi khusus komik.

\section{Komodifikasi Konten}

Politik ekonomi komunikasi berbicara tentang proses komoditas, yang poin utamanya adalah perihal isi dari media tersebut dengan mengubah nilai guna menjadi nilai tukar. Komodifikasi isi berkaitan tentang isi dari suatu media sangat cocok dijual dipasaran karena sesuai dengan minat pasar. Secara spesifik, proses komodifikasi komunikasi melibatkan transformasi pesan, mulai dari bit data ke sistem pemikiran yang berarti, menjadi produk yang dapat dipasarkan (Mosco, 2009). Isi media menjadi pasar untuk dijual karena berisikan simbol, makna, gambar, informasi, dan lainnya yang sesuai dengan minat pasar. Komodifikasi konten atau isi media dan format media tetap harus diukur dan dipantau agar selalu menjadi paket komplit untuk diperdagangkan.

Vincent Mosco mengatakan, bahwa komodifikasi konten berkaitan dengan isi dari suatu media komunikasi. Dalam hal ini, peneliti melihat bahwa isi yang dibuat sedemikian rupa dalam setiap genreLINE Webtoon berkaitan dengan kebutuhan dari para pembacanya. Oleh karena itu, tidak heran bahwa kreator menjadikan kolom komentar sebagai salah satu dari sumber ide atau inspirasi serta pemanis bagi episode berikutnya. Hal tersebut dilakukan agar para pembaca terbawa arus dan imajinasi mereka bisa terealisasikan. Menurut peneliti, hal ini merupakan strategi yang sangat bagus, karena pembaca seakan-akan dibuat sebagai agen yang turut serta dalam membuat alur cerita.

Berdasarkan persyaratan yang diberikan oleh LINE Webtoon mengenai konten atau isi cerita, ada beberapa poin yang peneliti lihat bahwa sebenarnya tidak dijalani dengan benar sesuai aturan tertulis tersebut dan seakan hanya sebagai persyaratan saja. Peneliti melihat di sini seperti ada kekuasaan di balik itu semua untuk mengambil keuntungan dari perkembangan teknologi komunikasi tanpa benar-benar menjalani syarat dan ketentuan yang berlaku. Berdasarkan data yang didapat, genre romantis dan drama merupakan genre yang paling banyak diminati oleh para pembaca di Indonesia.

Sependalaman peneliti terhadap syarat dan ketentuan yang diberikan LINE Webtoon tentang konten yang tidak layak, menurut peneliti syarat tersebut masih belum dijalani dengan sempurna. Hal ini dikarenakan adanya konten pada beberapa judul webtoon yang melanggar persyaratan tentang konten yang tidak layak dan berbanding terbalik dengan misi LINE Corporation mengenai menghargai budaya setempat. Peneliti melihat, bahwa mereka mengubah konten tidak layak itu menjadi nilai jual yang ditawarkan sebagai bahan jualan mereka kepada pembaca. Hal ini menjadi kasus yang sangat penting untuk dikritisi, karena mengingat LINE Webtoon sebagai perusahaan media baru di Indonesia yang sedang berkembang. Sehingga masih bisa untuk dibatasi dan diarahkan sesuai dengan ketentuan hukum yang berlaku di Indonesia.

Salah satu kelemahan dari media baru, khususnya komik online yang sedang naik daun akhir-akhir ini, yaitu belum adanya peraturan yang mematenkan tentang salah benar atas konten yang disebarkan ke masyarakat luas di Indonesia. Seperti televisi 
National Conference of Creative Industry:

Sustainable Tourism Industry for Economic Development

Universitas Bunda Mulia, Jakarta, 5-6 September 2018

ISSN No: 2622-7436

mempunyai KPI (Komisi Penyiaran Indonesia) yang mengatur segala sesuatunya tentang konten yang layak atau tidak untuk ditayangkan. Namun, belum ada untuk penggunaan webtoon.

Pada daftar tentang syarat dan ketentuan konten pada LINE Webtoon di Indonesia tertulis bahwa konten yang tidak layak di dalamnya termasuk tentang konten cabul; berarti konten yang dianggap berbahaya bagi orang yang belum dewasa karena adanya keterbukaan yang berlebihan serta secara eksplisit menggambarkan tindakan seksual.

Menurut peneliti, ada beberapa judul webtoon yang terbit di LINE Webtoon Indonesia yang melanggar persyaratan ini, padahal judul tersebut merupakan akun official dan melalui proses pemilihan terlebih dahulu oleh editor untuk disebarkan di Indonesia.

Peneliti melihat adanya konten-konten yang bernuansa cabul yang menurut LINE Webtoon berarti konten yang dianggap berbahaya bagi orang yang belum dewasa karena adanya keterbukaan yang berlebihan serta secara eksplisit menggambarkan tindakan seksual. Hal tersebut digambarkan dengan jelas dan menarik baik melalui gambar serta kata-kata yang tertera di dalamnya, sehingga pembaca dapat terbawa imajinasinya untuk menikmati konten tersebut.

Hal di atas tentu berbanding terbalik dengan misi utama LINE Corporation asal Jepang yang menaungi webtoon yang masuk dari Korea di Indonesia. Misi LINE Corporation adalah untuk membawa orang,informasi dan layanan menjadi lebih dekat.LINE telah tumbuh menjadi platform sosial dengan ratusan juta khalayak di seluruh dunia, memiliki fokus yang sangat kuat di benua Asia yang berkembang pesat. Dalam misinya tertera kalau LINE Corporation percaya bahwa penting untuk menghormati budaya dan norma masing-masing negara untuk melibatkan khalayak pada tingkat yang sangat dalam dan berevolusi di setiap wilayah. LINE Corporation menyebutnya sebagai budaya dan itu adalah inti dari semua yang LINE Corporation lakukan. Namun kenyataannya masih ada pada konten-konten di LINE Webtoon yang tidak sesuai dengan kebudayaan Indonesia.

\section{Komodifikasi Audiens}

Dallas Smythe (1977, dalam Mosco 2009) mengatakan bahwa audiens atau khalayak adalah komoditas utama bagi media. Kemunculan media baru memperkuat agrumen Smythe (Shimpach, 2015). Sistem digital memperkuat dan memperluas proses komodifikasi sehingga dapat dikomunikasikan kepada audiens lebih effisien dan efektif. Sistem digital memberikan kemudahan dalam hal mengukur dan memantau secara tepat setiap transaksi informasi yang digunakan saat ini untuk menyaring proses pengirimanrating penonton, pendengar, pembaca, penggemar film, khalayak telepon dan komputer, kepada pengiklan.

Komodifikasi khayalak berkaitan tentang rating yang diterima dari konten media, dan rating tersebut dijual kepada pengiklan dengan menggunakan khayalak sebagai tolak ukurnya. LINE Webtoon mengubah nilai guna dari rating menjadi nilai tukar kepada pengiklan, agar para pengiklan mau mengisi dan membeli slot iklan yang ada di LINE Webtoon. Maksudnya, ketika suatu konten disebarkan melalui media komunikasi kepada khalayak, dan konten tersebut diminati oleh khalayak, maka akan semakin tinggi jumlah konsumsi dan nilai rating media tersebut. Hal ini sangat berguna bagi politik ekonomi media, karena salah satu pendapatan media adalah melalui iklan. 
Pengiklan biasanya akan memilih dengan cermat media komunikasi mana yang akan mereka gunakan untuk mengiklankan produk mereka dan sesuai dengan target pasar mereka. Maka dari itu, pada tahap ini, audiens dikomodifikasikan oleh media komunikasi kepada sang pengiklan. Produk dari iklan tersebut akan dikonsumsi kembali oleh audiens dan memiliki kemungkinkan untuk terjadinya proses pembelian atau konsumsi. Jadi berputar seperti itu terus menerus.

Pembaca LINE Webtoon di Indonesia merupakan yang terbanyak dari Negara lainnya. Setiap bulannya pembaca mencapai kurang lebih enam juta orang. Pembaca di Indonesia pun juga sangat aktif pada kolom komentar di setiap episode LINE Webtoon untuk memberikan tanggapan langsung. Selain komentar, para pembaca juga turut aktif memberikan "rating" dan "favorite" pada judul-judul webtoon yang mereka sukai. Sehingga pihak LINE Webtoon dan para kreator mendapatakan feedback dengan cepat.

Feedback ini dijadikan mereka sebagai acuan terhadap nilai jual selanjutnya agar mereka tidak kehilangan para pembaca sebagai pasar untuk mereka berjualan. Peneliti melihat bahwa masyarakat di Indonesia telah menarik perhatian LINE Webtoon yang merupakan perusahaan kerja sama antara Jepang dan Korea sebagai pasar potensial mereka.

Salah satu LINE Webtoon yang menarik perhatian peneliti adalah Eggnoid, hal ini dikarenakan Eggnoid merupakan satu-satunya webtoon asal Indonesia yang bisa menembus pasar Global dalam Bahasa Inggris. Selain itu, Eggnoid juga terbit dalam bahasa Thailand, Taiwan, China dan Jepang. Eggnoid terbit secara online di Indonesia pada aplikasi LINE Webtoonsejak 13 Desember 2015 hingga saat ini. Eggnoid season satu terdiri dari 31 episode yang terbit sejak 13 Desember 2015 hingga 26 Juni 2016. Eggnoid season 2 terbit sejak 31 Juli 2016 hingga saat ini sudah mencapai 32 episode per 18 Maret 2018 dan masih berlanjut. Di-subscribe lebih dari 3 juta, disukai lebih dari 10 juta, Rating 9,75 dari skala 10.

Eggnoid mulai terbit secara Internasional berbahasa Inggris sejak 11 Nov 2017 hingga saat ini 19 Maret 2018 sudah memasuki season 2 episode 28. Disukai oleh 1,8 juta khalayak internasional, rating 9,75 dari skala 10. Berdasarkan penelitian yang dilakukan peneliti, hampir disetiap episode pada Eggnoid terdapat iklan di bagian bawah dekat dengan kolom komentar.

Menurut peneliti, hal ini dilakukan pengiklan karena mereka merasa melihat tingkat kepopuleran Eggnoid dan bisa memanfaatkan setiap audiens yang membaca Eggnoid mengkonsumsi produk dari iklan mereka, seperti yang tertulis pada buku Vincent Mosco.

Di Indonesia, Eggnoid mendapatkan iklan Cornetto yang dimasukkan ke dalam webtoon khusus iklan "Gombalan Goceng" episode 7. Terbit 17 Maret 2018, Per 22 Maret 2018 disukai oleh 38.142 orang (dalam 5 hari). Selain Eggnoid, juga ada beberapa judul webtoon dari berbagai genre yang banyak disukai oleh audiens, yang masuk ke dalam webtoon khusus iklan "Gombalan Goceng". Selain melalui serial webtoon "Gombalan Goceng", Cornetto juga melakukan iklan dengan mengadakan kuis melalui akun sosial media LINE Webtoon.

Dengan banyaknya jumlah pembaca di Indonesia, hal ini dimanfaatkan oleh salah satu industri webdrama Korea yang berjudul "Seventeen" untuk mempromosikan webdrama-nya dengan cara memberikan cuplikan-cuplikan adegan pada webdrama tersebut ke dalam bentuk webtoon yang dibintangi oleh beberapa artis Korea. Peneliti melihat hal ini sebagai bentuk kekuasaan Korea atas kepemilikan webtoon dari Negara 
National Conference of Creative Industry: Sustainable Tourism Industry for Economic Development

Universitas Bunda Mulia, Jakarta, 5-6 September 2018

ISSN No: 2622-7436

asalnya. Karena, menurut peneliti hal ini tidaklah adil bagi kreator Indonesia yang memang membuat komik atas dasar lukisan tangan mereka dan bukan menggunakan adegan orang secara asli, lalu harus melalui proses Webtoon Challenge terlebih dahulu, dan dinilai oleh para editor apakah layak atau tidak untuk terbit sebagai akun official. Sedangkan industri webdrama Korea yang berjudul "Seventeen" masuk dengan mudahnya menjadi akun official tanpa melalui proses Webtoon Challenge dan LINE Webtoon tidak mematuhi ketentuan yang mereka buat sendiri tentang menjadi akun official. Hal tersebut bukan atas dasar relevan dengan masyarakat atau berdasarkan kebutuhan masyarakat, namun peneliti melihat hal ini karena memang untuk memasarkan industri webdrama asal Korea. Webdrama "Seventeen" tayang di Korea sejak 27 April 2017 di NAVER TV dalam delapan episode. Terbit sebagai webtoon sejak tanggal 28 Juni 2017 hingga 21 Juli 2017 dalam delapan episode.

Berdasarkan data ini, peneliti menemukan bahwa webdrama tersebut merupakan karya dari NAVER TV, di mana webtoon juga merupakan satu grup dengannya yaitu NAVER WEBTOON. Menurut peneliti, di sini sudah sangat terlihat jelas bahwa LINE Webtoon berada di bawah kendali NAVER WEBTOON. Adanya kekuatan dominan dari negara Korea yang merupakan pencetus webtoon. Sehingga, mereka memiliki kekuatan untuk mulai melakukan promosi dunia hiburan mereka melalui webtoon untuk mengincar pasar Indonesia lebih luas lagi.

\section{Komodifikasi Pekerja}

Kemajuan teknologi komunikasi meningkatkan komodifikasi pada pekerja media. Komodifikasi pekerja media adalah berkaitan tentang tugas mereka dalam produksi dan distribusi produk media yang mungkin tidak sesuai antara beban kerja dengan upah yang didapat. Korporasi memanfaatkan pekerja untuk mendapatkan keuntungan. Tantangan yang harus dihadapi adalah menguji politik ekonomi media khususnya pada komodifikasi pekerja media dalam proses produksi media.

LINE Webtoon hadir di Indonesia seakan memfasilitasi kreator - kreator berbakat asal Indonesia yang tidak memiliki tempat untuk mempublikasikan karya mereka. Platform pada LINE Webtoon seakan memberikan kemudahan dan kesempatan bagi mereka untuk mempublikasikan karya kepada khalayak luas melalui fasilitas Webtoon Challenge. Para kreator tidak akan menerima bayaran sedikit pun dari LINE Webtoon. LINE Webtoon hanya akan menggaji para kreator yang sudah diangkat menjadi akun official mereka.

Kreator yang memproduksi semuanya sendiri, lalu mempublikasikan sendiri. LINE Webtoon memfasilitasi antara kreator dengan para pembaca. Webtoon Challenge seakan menjadi tempat pengukiran sejarah antara kreator dan pembaca ketika judul webtoon dari kreator tersebut berhasil menjadi akun official. Antara kreator dan pembaca bersama-sama berusaha dalam memberikan rating, menyebarkan judul webtoon dan menekan pilihan favorite untuk menambahkan popularitas dari para kreator pemula. Para kreator pemula yang berhasil mendapatkan respon terbanyak akan menduduki lima besar atau lima teratas dalam halaman webtoon chalengge, hal ini memberikan benefit bagi kreator karena karyanya menjadi semakin dilihat oleh pembaca.

Bagi para kreator di Webtoon Challenge, jika ingin mendapatkan bayaran atau benefit dari karyanya, dapat turut serta dalam perlombaan Rising Star. Rising Star adalah program dari LINE Webtoon untuk menyemangati para kreator yang sedang 
National Conference of Creative Industry: Sustainable Tourism Industry for Economic Development

Universitas Bunda Mulia, Jakarta, 5-6 September 2018

ISSN No: 2622-7436

menerbitkan webtoon di Webtoon Challenge agar terus berkarya membuat komik terbaik. Melalui program Rising Star, kreator di Webtoon Challengeberkesempatan memenangkan hadiah sebesar 5 juta rupiah. Untuk berpartisipasi di Rising Star, hanya dapat dilakukan oleh kreator yang menerbitkan komik di Webtoon Challenge melalui situs LINE Webtoon versi PC/komputer, kreator tidak sedang terikat kontrak dengan penerbit lain baik cetak ataupun digital, melakukan update lebih dari tiga kali (minimal empat episode) selama tiga bulan terakhir, jumlah favorite lebih dari 3.000 dan jumlah view lebih dari 50.000. Penilaian dilakukan oleh editor dengan kriteria penilaian yang terdiri dari ciri khas $40 \%$, jalan cerita atau konten $30 \%$, artistik $20 \%$ dan reaksi pembaca $10 \%$.

Pada minggu pertama, editor akan menyeleksi dan memilih lima webtoon challenge yang sesuai dengan kriteria, kemudian pada minggu kedua akan diadakan pengumuman kepada pembaca agar bersiap untuk memilih di antara kelima webtoon challenge yang menjadi kandidat Rising Star. Lalu pada minggu ketiga, pembaca mulai memilih maksimal dua judul terhitung dari hari Senin sampai dengan Jumat. Pengumuman akan dilakukan pada minggu ke empat. Pemenang Rising Star tidak dijamin langsung menjadi akun resmi atau akun official dari LINE Webtoon. Editor memiliki banyak pertimbangan untuk menjadikan sebuah karya di Webtoon Challenge menjadi karya resmi di LINE Webtoon.

Peneliti melihat hal ini merupakan politik ekonomi media yang dilakukan oleh LINE Webtoon dengan memanfaatkan para kreator pemula untuk mendapatkan konten sebanyak-banyaknya tanpa melakukan pembayaran kepada mereka. Peneliti memahami untuk menjadi kandidat Rising Star saja sudah sangat sulit syarat-syarat yang diberikan. Selain itu, setelah jadi Rising Star mereka belum tentu dan/atau tidak otomatis langsung menjadi akun official. Menurut peneliti, hal ini sebagai "topeng" mereka dengan memfasilitasi kreator pemula, namun tidak memberikan bayaran kepada para kreator itu, tidak bertanggung jawab atas plagiasi terhadap konten di masa mendatang, dan lainnya. Kalau dari persyaratan yang ditangkap oleh peneliti, keuntungan mayoritas berada di pihak LINE Webtoon.

Para kreator yang sudah menjadi akun official pun diberikan beban kerja dengan deadline setiap minggu dengan minimal 30 panel setiap episodenya. Peneliti mendapatkan data bahwa segala peralatan yang digunakan untuk membuat webtoon merupakan peralatan pribadi kreator yang mereka beli sendiri. Peneliti melihat bahwa LINE Webtoon benar-benar memanfaatkan para kreator dengan mengubah nilai guna mereka baik dari segi kemampuan hingga karya menjadi nilai yang ditukar atau dijual dipasaran. LINE Webtoon mengeluarkan bayaran untuk gaji para akun official, namun segala proses produksi dari awal hingga jadi sebuah karya dalam bentuk episode dalam webtoon, bebannya ditanggung oleh kreator. LINE Webtoon seakan sebagai penampung karya, namun memberikan tanggung jawab produksi kepada kreator baik dari segi konten yang harus sesuai dengan minat pasar, deadline, dan banyaknya panel dalam setiap episode. Peneliti melihat, kreator seakan dibuat merasa kehadiran webtoon memberikan kesempatan bagi mereka untuk berkarya, namun peneliti mengkritisi bahwa hal ini sebagai salah satu praktik komodifikasi pekerja yang dilakukan oleh LINE Webtoon.

Kasus lainnya pada webtoon "Seventeen" yang merupakan cuplikan dari webdrama juga menarik perhatian peneliti untuk memperkuat bahwa LINE Webtoon benar-benar hadir untuk melakukan politik ekonomi media baru di Indonesia dan 
memanfaatkan pasar serta pekerja atau kreator di Indonesia untuk memperbesar perusahaannya. Tanpa melalui Webtoon Challenge, webtoon "Seventeen" langsung masuk sebagai akun official LINE Webtoon di Indonesia. Menurut peneliti, hal ini memberikan kerugian bagi para kreator yang memang merintis dari awal melalui Webtoon Challenge. Karena kekuasaan yang dimiliki NAVER Corporation, webtoon "Seventeen" hasil cuplikan adegan-adegan dari webdrama NAVER TV masuk dengan mudah ke dalam LINE Webtoon di bawah kendali NAVER WEBTOON.

\section{Spasialisasi dalam LINE Webtoon Indonesia}

Spasialisasi membahas tentang penyebaran produk oleh media kepada audiens atau khalayak tanpa terhalang oleh ruang dan waktu dengan memanfaatkan kemajuan teknologi komunikasi, sehingga memberikan kemudahan bagi para pembaca untuk mengakses LINE Webtoon dimana pun dan kapan pun. LINE Webtoon Indonesia selalu update setiap harinya tepat jam 22.00 WIB. Misalnya untuk judul dengan jadwal tayang hari Selasa, maka judul tersebut akan terbit di hari Senin jam 22.00 WIB. Jika ada webtoon yang tidak terbit, maka akan ada pemberitahuan, permintaan maaf, serta alasan tidak terbit atau terlambat terbit dari para kreator secara khusus kepada para pembaca. Terciptanya ruang sosial sebagai produk yang ditawarkan kepada publik sebagai produk sosial dalam jaringan internet, menjadikan ruang tersebut sebagai alat bertukar informasi, berfikir, dan bertindak. Hal ini berkaitan dengan bentuk atau jenis teknologi yang digunakan, jaringan, hingga kecepatan distribusi dengan berbagai cara, hingga integrasi yang dimiliki oleh perusahan baik secara vertikal atau pun horizontal.

Ruang yang dimaksud pada masa kini, bukan lagi berbicara tentang ruang atau jarak secara fisik atau geografis lokal dan global, namun lebih kepada transformasi ruang dalam bentuk jaringan internet yang dapat mencapai ruang lokal dan global tanpa dipengaruhi perbedaan lokasi geografis yang nyata. Meskipun terdapat perbedaan waktu antara wilayah yang satu dengan wilayah yang lainnya, namun pendistribusian dapat dilakukan secara bersamaan. Proses dari mulai produksi, distribusi, konsumsi, termasuk sumber komunikasi disebarkan secara bersamaan kepada audiens. LINE Webtoon Indonesia memberikan fasilitas berbagai pilihan bahasa resmi untuk para pembaca, mulai dari Bahasa Indonesia, Bahasa Taiwan, Bahasa Thailand dan Bahasa Inggris. Selain bahasa resmi, pembaca juga dapat mengakses webtoon dengan terjemahan bahasa yang dilakukan oleh penggemar, disebut "Fan Translation". Jadi, hal ini memberikan kemudahan bagi para pembaca untuk memilih bahasa apa yang ingin mereka gunakan.

Tidak hanya berhenti sampai di situ, spasialisasi juga berbicara tentang kontrol serentak yang dilakukan oleh pihak yang berkuasa atas media komunikasi. Berdasarkan syarat dan ketentuan yang tertulis mengenai konten yang tidak layak, termasuk di dalamnya tentang konten yang mempromosikan perjudian atau konten komersial yang berarti; konten yang termasuk konten komersial untuk mempromosikan perusahaan tertentu atau demi keuntungan individu itu sendiri. Dalam hal ini peneliti melihat kontrol atas pihak yang berkuasa yaitu NAVER Corporation untuk menyebarkan webdrama "Seventeen" di Indonesia melalui LINE Webtoon demi mendapatkan keuntungan untuk pihak NAVER TV dan NAVER Webtoon. Peneliti melihat, praktik ini seakan sebagai perluasan jaringan bisnis mereka di Indonesia. NAVER CORP seakan sadar bahwa pasar Indonesia merupakan pasar yang potensial dalam segi 
pembaca webtoon, maka dari itu mereka mulai melakukan promosi perluasan bisnis webdrama melalui LINE Webtoon.

Perubahan dalam struktur industri, teknologi, layanan, dan kebijakan membuat kesulitan dalam memetakan konsentrasi media. Untuk mempermudah, spasialisasi dibagi atas dua konsentrasi yaitu horizontal dan vertikal. Spasialisasi horizontal adalah konsentrasi yang menyatukan industri media dengan cara memperluas produksi dan sumber daya media dengan cara membeli saham atau mengakuisisi media lain yang sama jenisnya dan setara. Spasialisasi vertikal adalah konsentrasi yang menggambarkan konsentrasi perusahaan-perusahaan dalam suatu lini bisnis yang memperluas kendali perusahaan atas proses produksi. Spasialisasi dilakukan untuk memperluas jangkauan media kepada khalayak luas. Spasialisasi vertikal dapat terjadi antar negara, di mana salah satu perusahaan sebagai perusahaan induk dan satu lagi sebagai anak perusahaan. Salah satu dampak dari proses spasialisasi adalah akan terjadi monopoli media komunikasi.

Menurut penelitian yang sudah dilakukan, spasialisasi yang dilakukan oleh LINE Webtoon adalah spasialisasi vertikal, karena penyebaran dilakukan antar negara, di mana LINE Webtoon sekarang sudah menjadi platform terbesar untuk masyarakat mengakses komik dalam bentuk media baru di Indonesia. LINE Webtoon sebagai pionir atas inovasi ini dan membuat perusahaan webtoon lainnya mulai bermunculan di Indonesia, namun tidak seterkenal LINE Webtoon, contohnya seperti Comica, Baca Manga Komik Indonesia, dan lainnya.

Berdasarkan penelitian yang telah dilakukan, peneliti ingin mengkritisi tenang spasialisasi yang berkaitan dengan batas usia. LINE Webtoon menuliskan bahwa syarat pengguna adalah usia 14 tahun. Namun masih ada beberapa konten yang tidak layak untuk diakses oleh anak di bawah 17 tahun. Kelemahan pada websiteLINE Webtoon adalah siapa pun bisa baca tanpa melakukan pendaftaran terlebih dahulu. Hanya akan keluar peringatan dan jika kita klik "oke" kita langsung bisa akses webtoon tersebut tanpa ada pembatas yang ketat. Jika melalui aplikasi, pembaca diwajibnya masuk melalui akun LINE terlebih dahulu. Namun, pada konten-konten yang bermuatan dewasa, hanya akan ada pengumuman tentang peringatan webtoon yang mengandung muatan dewasa. Bagi pembaca yang belum cukup umur atau tidak nyaman dengan konten dewasa, dianjurkan untuk tidak membacanya.

Menurut peneliti, ini sangat bahaya. Karena secara tidak langsung membawa pesan-pesan yang akan mempengaruhi perubahan budaya dan moral di Indonesia. Peneliti mencurigai bahwa hal ini sengaja, karena konten-konten yang bermuatan dewasa kenyataannya juga sangat disukai. Jika diamati melalui kolom komentar, pembaca sangat banyak yang merasa hal tersebut wajar saja dan sedikit yang mempersoalkan baik atau buruknya bacaan tersebut. Jika tidak dibatasi atau diatasi dengan cepat, di masa datang pasti hal ini akan sangat mempengaruhi budaya dan moral bangsa Indonesia.

\section{Strukturasi dalam LINE Webtoon Indonesia}

Strukturasi membahas tentang agen sebagai pembentuk suatu struktur dan struktur membentuk agen, sehingga menimbulkan terjadinya proses produksi dan reproduksi yang saling mempengaruhi satu dengan yang lainnya. Di dalamnya terjadi proses sosial antar agen untuk saling menukarkan idenya. Terjadi interaksi antara struktur dan agen sosial yang dinamis dan saling mempengaruhi antara satu sama lain. 
National Conference of Creative Industry:

Sustainable Tourism Industry for Economic Development

Universitas Bunda Mulia, Jakarta, 5-6 September 2018

ISSN No: 2622-7436

Peneliti melihat bahwa keberhasilan seorang kreator sebagai akun official bukan saja karena karyanya yang bagus, namun juga karena peran masyarakat atas minat membaca judul webtoon tersebut dan keterlibatan pembaca dalam memberikan masukkan untuk memperluas imajinasi para kreator sehingga cerita yang disampaikan ditambahkan bumbu-bumbu pemanis dan semakin laku dipasaran pembaca.

Dalam teori politik ekonomi komunikasi Vincent Mosco, proses stukturasi dapat menimbulkan adanya tindakan dan perubahan sosial yang dipengaruhi oleh struktur sosial seperti kelas, gender, ras, gerakan sosial dan hegemoni (dominasi terhadap negara lain). Peneliti melihat bahwa LINE Webtoon sendiri tidak membedakan kelas dan ras para pembacanya. Baik kelas bawah sampai kelas atas dapat mengakses LINE Webtoon asalkan tehubung dengan jaringan internet dan dapat mengakses aplikasi atau website LINE Webtoon. Untuk gender, baik pria maupun wanita memiliki ketertarikan dalam membaca LINE Webtoon, yang membedakannya adalah selera dari genre bacaan antara pembaca wanita dan pembaca pria. Webtoon Line menguasai pangsa pasar pembaca komik yang beralih dari cetak menjadi digital. Webtoon Line menjadi aplikasi komik berbasis online terbesar di Indonesia dengan jumlah pembaca 6 juta tiap bulannya berdasarkan data tahun 2016-2017. Melalui LINE Webtoon, peneliti melihat bahwa ternyata masyarakat Indonesia suka membaca dan menjadi pasar yang dilirik oleh NAVER WEBTOON. Hal ini meningkatkan gerakkan suka membaca di tengah masyarakat. LINE Webtoon menawarkan kemudahan bagi masyarakat untuk mulai menyukai membaca kapan saja dan dimana saja, khususnya bagi para remaja dan pemuda di Indonesia.

Strukturasi politik ekonomi komunikasi berkaitan dengan gerakkan sosial yang ada di masyarakat. Gerakkan sosial saat ini tidak lagi dibatasi dengan pergerakkan nyata, namun juga bisa dengan dukungan atau partisipasi secara online melalui media berjaringan internet. Pembaca dengan sendirinya berlomba-lomba memberikan tanggapan atas setiap judul yang mereka baca untuk menjadi yang pertama mendapatkan gelar "best comment" yang dipilih oleh pembaca lainnya. Menurut peneliti, hal ini sangat bagus, karena secara tidak langsung melatih para pembaca untuk lebih responsif dan berani dalam menyampaikan pendapat mereka.

Selain dari segi pembaca, LINE Webtoon juga hadir untuk menggerakkan serta meningkatkan kembali semangat para komikus yang tidak punya wadah untuk beraksi melalui Webtoon Challenge. Hal ini membuat para kreator pemula di Indonesia berani untuk unjuk gigi tentang kebisaan mereka dalam hal menggambar dan tidak kalah dengan kreator luar negeri. Salah satu contohnya Archie, kreator Eggnoid, yang sangat mengharumkan nama Indonesia di pasar luar negeri mulai dari Taiwan, Thailand, Jepang, hingga Global (dalam Bahasa Inggris). Hal ini membuktikan bahwa kreator asal Indonesia sangat mampu untuk bersaing dengan kreator luar negeri dan Indonesia memiliki sumber daya manusia yang dapat diperhitungkan.

Strukturasi menciptakan hegemoni sebagai cara pandang dunia yang diterima begitu saja. Peneliti melihat hegemoni dari sudut pandang kritis bahwa cara pandang dunia tersebut diterima bagitu saja karena ada kekuasaan yang memonopoli dunia hiburan tanah air mulai dari drama, film, reality show, hingga ke komik online saat ini sebagai trend terbaru. Dalam hal ini, peneliti melihat bahwa Jepang dan Korea bekerja sama untuk menyebarkan produknya ke Indonesia. Dimulai dengan webtoon tahun 2015, lalu dua tahun kemudian mulai menyebarkan webdrama melalui webtoontahun 2017, di masa datang mungkin akan ada beberapa strategi lagi yang akan mereka 
National Conference of Creative Industry: Sustainable Tourism Industry for Economic Development

Universitas Bunda Mulia, Jakarta, 5-6 September 2018

ISSN No: 2622-7436

lakukan untuk menjangkau pasar Indonesia. Pasar di Indonesia dengan mudah menerima dan mengkonsumsi produk dari Jepang dan Korea, sehingga sudah terbukti bahwa saat ini LINE Webtoon menjadi satu-satunya platform komik online terbesar dan paling banyak diminati di Indonesia.

Hal yang menjadi perhatian peneliti adalah, dengan kemajuan teknologi memudahkan perusahaan serta budaya luar masuk ke Indonesia dan terintegrasi dengan budaya lokal, sehingga diterima begitu saja oleh masyarakat karena sesuai dengan kebutuhan masyarakat. Peneliti pun juga melihat belum ada aturan atau pembatas yang jelas dari Pemerintah Indonesia dalam menangani kemajuan teknologi komunikasi media baru khusunya pada komik online.

\section{Pembahasan Hasil Penelitian}

Peneliti mendapatkan hasil dari penelitiaan ini berdasarkan data yang didapat serta analisis yang telah dilakukan yang akan dibahas dalam sub bab ini. LINE Webtoon merupakan komik elektronik yang dapat diakses melalui website dan aplikasi dengan mudah dan menggunakan jaringan internet. LINE Webtoon merupakan suatu produk hasil kerjasama antara LINE Corporation yang berasal dari Jepang dan Naver Webtoon Corp yang berasal dari Korea. LINE Webtoon dapat didownload melalui playstore maupun appstore.

LINE Webtoon merupakan inovasi terbaik bagi para pencinta komik sehingga mempermudah dan membuat komik jadi lebih hidup dengan gambar tiga dimensinya. Jadwal updateLINE Webtoon di Indonesia setiap hari Senin jam 22.00 WIB. Isi dari LINE Webtoon dibedakan sesuai kategori seperti, romantis, drama, fantasi, horror, komedi, thriller, dan slice of life. Dalam setiap kategori terdapat beberapa judul komik. LINE Webtoon terbit secara online di Indonesia pada 2014 hingga saat ini. Pasar Indonesia merupakan pasar yang menjanjikan dan menurut data survey tahun 20162017, Indonesia memiliki pembaca terbanyak LINE Webtoon. Di Indonesia, Pengiklan merk Cornetto yang dimasukkan ke dalam webtoon khusus iklan "Gombalan Goceng".

Terdapat beberapa LINE Webtoon asli Indonesia yang sudah terbit ke pasar Internasional, salah satunya Eggnoid. Kreator Eggnoid bernama Archie, merupakan salah satu dari 3 Kreator Indonesia yang sudah go internasional melalui LINE Webtoon. Karyanya sudah dapat dinikmati dalam lima bahasa, yaitu Indonesia, Inggris, Thailand, Mandarin dan Jepang.

Selain LINE Webtoon yang sudah resmi rilis, ada juga Webtoon Challange tempat para kreator untuk mengupload karyanya pada platform LINE Webtoon. Bedanya, para kreator LINE Webtoon yang sudah resmi rilis akan mendapatkan penghasilan atau bayaran dari pihak LINE, sedangkan para kreator di Webtoon Challange tidak mendapatkan bayaran sama sekali walaupun karyanya sudah menjadi bahan konsumsi. Webtoon Line menguasai pangsa pasar pembaca komik yang beralih dari cetak menjadi digital. Webtoon Line menjadi aplikasi komik berbasis online terbesar di Indonesia dengan jumlah pembaca 6 juta tiap bulannya berdasarkan data tahun 2016-2017.

Pada LINE Webtoon masih terdapat peraturan yang bias mengenai konten terutama tentang konten yang tidak layak. Hal ini berbanding terbalik dengan syarat yang tertera serta misi LINE Webtoon. Seharusnya LINE Webtoon dapat memberikan batasan yang jelas tentang apa yang tertulis dalam aturan dengan apa yang dipraktekkan. Sehingga tidak menimbulkan bias bagi para pembaca dan kreator di masa 
mendatang. Pemerintah juga sebaiknya turut campur tangan dalam menangani kasus ini agar dapat diatasi atau dicegah secepat mungkin sebelum menimbulkan dampak yang besar. Pemerintah dapat mengeluarkan regulasi yang mengatur segala sesuatu tentang komik online sejenis LINE Webtoon.

Para audiens yang merupakan pembaca aktif LINE Webtoon menjadi pangsa pasar utama bagi NAVER Webtoon. Hal ini dikarenakan Indonesia memiliki jumlah pembaca LINE Webtoon tertinggi dibandingkan negara lain. Pasar Indonesia menjadi pasar yang sangat menjanjikan bagi LINE Webtoon. Selain pembaca, kreator asal Indonesia juga banyak yang turut serta dalam Webtoon Challenge. Namun kelemahan Webtoon Challenge dari sisi politik ekonomi media adalah tidak adanya bayaran sama sekali bagi mereka yang turut aktif berpartisipasi. Para kreator memiliki kesempatan untuk mendapatkan bayaran atau uang jika mengikuti perlombaan Rising Star. Namun tidak sembarangan kreator yang bisa ikut. Kreator tetap harus bisa memenuhi kriteria yang akan dipilih oleh para editor, baru ditentukan oleh pembaca. Menurut peneliti, kriteria yang diberikan sebaiknya bisa dipermudah agar lebih banyak kreator yang mendapatkan kesempatan untuk masuk kriteria Rising Star.

LINE Webtoon di Indonesia masuk melalui website dan aplikasi. Siapa pun bisa mengaksesnya asalkan memiliki perangkat dan tersambung dalam jaringan internet. Ketepatan waktu update, variasi bahasa, dan penyebaran yang dapat menembus ruang dan waktu membuat LINE Webtoon dapat diakses kapan pun, dimana pun, dan oleh siapa pun. Hal ini menjadi perhatian peneliti, karena kemudahan dalam mengakses termasuk konten yang kurang layak bagi anak di bawah umur, seharusnya LINE Webtoon meningkatkan kualitas dari aplikasi atau website-nya sehingga bisa lebih aman untuk diakses. Pemerintah juga sebaiknya lebih mengontrol penyebaran media melalui jaringan internet semacam ini agar dapat mencegah serta mengarahi perkembangan teknologi serta aktifitas politik ekonomi media ke arah yang lebih positif, tanpa mengutamakan keuntungan semata.

Pembaca, kreator, dan pihak LINE Webtoon masing-masing berperan sebagai agen dan struktur kemudian menjadi agen lagi dan struktur lagi yang saling mempengaruhi antara satu dengan lainnya. Dalam teori politik ekonomi komunikasi Vincent Mosco, proses stukturasi dapat menimbulkan adanya tindakan dan perubahan sosial yang dipengaruhi oleh struktur sosial seperti kelas, gender, ras, gerakkan sosial dan hegemoni (dominasi terhadap negara lain). Di Indonesia, LINE Webtoon telah menduduki nomor 1 sebagai platform komik online terbesar dan terbanyak diakses oleh audiens. Sebagai pionir komik online di Indonesia, LINE Webtoon sangat diminati oleh siapa saja baik dari kelas bawah sampai atas, dari ras apa pun, dan gender apa pun. Kehadiran LINE Webtoon juga membuat masyarakat di Indonesia khususnya remaja dan pemuda memiliki minat dalam membaca serta meningkatkan semangat berkarya bagi para kreator komik Indonesia.

\section{KESIMPULAN dan SARAN}

\section{Kesimpulan}

Indonesia menjadi Negara yang miliki pasar potensial bagi LINE Webtoon. LINE Webtoon merupakan produk hasil kerjasama antara Jepang dan Korea dalam membuat suatu media baru yang dapat diperdagangkan, salah satunya di Indonesia. LINE 
Webtoon menawarkan platform sebagai kesempatan bagi para kreator komik Indonesia untuk berkarya melalui fasilitas Webtoon Challenge.

Dalam teori politik ekonomi Vincent Mosco membahas tiga proses, yaitu komodifikasi, spasialisasi dan strukturasi. Komodifikasi dibagi menjadi tiga, yaitu komodifikasi konten, komodifikasi audiens dan komodifikasi pekerja. Konten dalam LINE Webtoon dibuat sebaik mungkin sehingga menarik minat pembaca. Saran atau masukan pembaca mengenai alur cerita juga biasanya dimasukkan oleh kreator sebagai tambahan ide dan pemanis setiap alur cerita yang mereka buat. Namun masih ada beberapa konten yang tidak layak untuk diakses oleh anak di bawah umur dan tidak sesuai dengan budaya serta moral bangsa Indonesia.

Komodifikasi audiens berkaitan dengan para pembaca yang berperan aktif dalam memberikan rating sehingga audiens ini menjadi bahan untuk dijual oleh LINE Webtoon kepada pengiklan. Terdapat satu produk yang dijual dalam bentuk webtoon di LINE Webtoon Indonesia, yaitu Walls Cornetto. Selain itu, karena pasar Indonesia bagus, ada satu webtoon yang merupakan webdrama korea yang dipasarkan kepada audiens di Indonesia yang berjudul "Seventeen". Ternyata webtoon tersebut berisikan cuplikan dari adegan-adegan para artis di webdrama "Seventeen" yang tayang pada NAVER TV yang masih satu grup dengan LINE Webtoon yaitu NAVER Corporations. Hal ini tentu merugikan para kreator Indonesia yang susah payah mengumpulkan imajinasi dan menggambar setiap penokohan serta alur ceritanya. Selain itu, para kreator yang masih berjuang pada Webtoon Challenge juga tidak mendapatkan bayaran atau pendapatan sama sekali. Pendapatan mereka bisa didapat melalui lomba Rising Star, namun kriteria untuk mengikuti lombanya pun juga sangat susah. Akun official pun mendapatkan tanggung jawab yang cukup tinggi mulai dari konten yang harus sesuai dengan minat pasar, deadline setiap minggu, dan minimal panel dalam setiap episodenya. Segala biaya proses produksi hingga penerbitan ditanggung oleh kreator. Kreator hanya mendapatkan gaji bulanan dari LINE Webtoon. Kreator dibuat seakan LINE Webtoon menyediakan ruang untuk berkarya, namun Peneliti lihat ini sebagai usaha LINE Webtoon mengubah nilai guna keahlian serta karya kreator menjadi nilai jual. Hal ini menjadi komodifikasi pekerja menurut Mosco, dimana para pekerja dibayar seminim mungkin sehingga perusahaan bisa mendapatkan penghasilan yang maksimal.

Spasialisai pada LINE Webtoon berkaitan dengan penyebaran konten yang dapat menembus ruang dan waktu beserta hambatan dan akibat yang mengikutinya, serta perluasan jaringan bisnis dari NAVER CORP yang memasukkan webdrama "Seventeen" ke dalam LINE Webtoon Indonesia. Hal tersebut juga berkaitan dengan ketidakadilan bagi kreator Indonesia yang berjuang sejak awal. Strukturasi berbicara tentang LINE Webtoonyang telah menjadi pionir komik online terbesar dan terbanyak diakses oleh pembaca di Indonesia. Selain itu, LINE Webtoon juga meningkatkan dan/atau membuktikan minat pembaca di Indonesia serta membangkitkan semangat para kreator komik di Indonesia untuk berkarya. LINE Webtoon seakan sebagai hegemoni Jepang dan Korea atas Indonesia. Jepang dan Korea bekerja sama untuk menjual produk yang benar-benar laku di pasar Indonesia. Namun, Pemerintah harus benar-benar bisa mengontrol pergerakkan ini agar tidak membawa dampak negatif bagi kebudayaan dan moral Bangsa Indonesia.

Peran Pemerintah sangat dibutuhkan untuk memagari sehingga dapat memberi batasan terhadap perkembangan teknologi agar bisa menuju ke arah yang positif. Belum 
ada peraturan Pemerintah yang secara nyata mengatur tentang konten apa yang boleh dan yang tidak boleh ditampilkan pada komik online khususnya LINE Webtoon.

\section{Rekomendasi}

- Rekomendasi Akademik

Peneliti berharap, di masa mendatang penelitian ini dapat dijadikan acuan sebagai penelitian sejenis yang membahas mengenai pergeseran budaya, kemajuan teknologi komunikasi, dan politik ekonomi media Vincent Mosco. Peneliti merekomendasikan untuk penelitian selanjutnya agar lebih bisa mengangkat peran Pemerintah dibalik masuknya perusahaan dan budaya luar ke Indonesia dari sisi Hegemoni.

- RekomendasiPraktis

Peneliti merekomendasikan agar para masyarakat dapat semakin cermat dalam memilih dan menggunakan media agar tidak menyingkirkan moral dalam berbangsa dan bernegara. Selain itu, untuk para pemilik media dan pemegang kekuasaan baik dari dalam atau pun luar negeri, dari sisi Politik Ekonomi Komunikasi agar lebih memperhatikan pekerjanya dan tidak mengkomodifikasikan mereka untuk mendapatkan keuntungan sebesar-besarnya dengan bayaran yang tidak seimbang. Terakhir untuk Pemerintah, agar bisa mengeluarkan aturan dan hukum yang berlaku secepatnya untuk media baru komik online perihal konten yang layak, sehingga ada acuan yang lebih jelas.

\section{DAFTAR PUSTAKA}

Adila, Isma. (2011). Spasialisasi Dalam Politik Ekonomi Komunikasi (Studi Kasus MRA Media). ISSN: 2088-981X.Jurnal Ilmu Komunikasi, Vol. 1, No.1, April 2011.

Diakses dari:http://jurnalilkom.uinsby.ac.id/index.php/jurnalilkom/article/view/14/10

Ardianto, Elvinaro. (2011). Metodologi Penelitian untuk Public Relations Kuantitatif dan Kualitatif. Bandung: Simbiosa Rekatama Media.

Bungin, Burhan.(2007). Penelitian Kualitatif : Komunikasi, Ekonomi, Kebijakan Publik, danIlmu Sosial Lainnya. Jakarta: Kencana.

Gusti Aji, Gilang. (2014). Spasialisasi dan Strukturasi Dalam Sistem Siaran Jaringan di Indonesia (Studi Kasus pada Kompas TV). Tesis Mahasiswa Universitas Indonesia kode panggil T41734.

https://m.suara.com/tekno/2017/08/02/193535/tren-terus-naik-line-webtoon-tembus-6juta-pembaca-tiap-bulan

https://www.viva.co.id/gaya-hidup/kuliner/843723-nurfadli-komikus-webtoonberpenghasilan-jutaan-rupiah

https://hot.detik.com/art/d-3274551/pembaca-line-webtoon-indonesia-terbesar-di-dunia

https://tekno.kompas.com/read/2017/10/28/13050097/penghasilan-kreator-line-bisaumrah-hingga-beli-rumah

Lee, Monle dan Johnson,Carla.(2011). Prinsip-Prinsip Pokok Periklanan Dalam Perspekstif Global. Jakarta: Kencana.

Littlejohn, Stephen, dan Foss, Karen A. (2008). Theories of Human Communication Ninth Edition.Boston: Wadsworth. 
National Conference of Creative Industry:

Sustainable Tourism Industry for Economic Development

Universitas Bunda Mulia, Jakarta, 5-6 September 2018

ISSN No: 2622-7436

Littlejohn, Stephen W., dan Foss, Karen A. (2009). Encyclopedia of Communication Theory 1. California: SAGE Publications, Inc.

Littlejohn, Stephen W., dan Foss, Karen A. (2009). Encyclopedia of Communication Theory2. California: SAGE Publications, Inc.

Littlejohn, Stephen, dan Foss, Karen A.(2009). Teori Komunikasi : Theories of HumanCommunication. Jakarta: Salemba Humanika.

McQuail, Denis. (2011). Teori Komunikasi Massa Mcquail Edisi 6. Jakarta: SalembaHumanika.

Moleong, Lexy J. (2010).Metodologi Penelitian Kualitatif. Bandung: PT Remaja Rosdakarya.

Morissan. (2013).Teori Komunikasi : Individu Hingga Massa.Jakarta: Kencana.

Morrisan. (2014).Periklanan : Komunikasi Pemasaran Terpadu. Jakarta: Kencana.

Mosco, Vincent. (2009). The Political Economy of Communication : Second Edition. London: Sage.

Mosco, Vincent and McKercher, Catherine. (2008). The Laboring of Communication: Will Knowledge Workers of The World Unite?. Lanham, MD: Lexington Books.

Pawito. (2007). Penelitian Komunikasi Kualitatif. Yogyakarta: LKis.

Raco,J.R. (2010).Metode Penelitian Kualitatif: Jenis, Karakteristik, dan Keunggulannya. Jakarta: Grasindo.

Sarwoprasodjo, Agung. (2008). Perbandingan Pendekatan Ekonomi Politik Media dan Studi Kebudayaan dalam Kajian Komunikasi Massa. ISSN: 1693-3699 Vol. 06, No.1, Februari 2008. Diakses dari: http://journal.ipb.ac.id/index.php/jurnalkmp/article/viewFile/5663/4294

Sendjaja, Sasa D. (2005).Komunika : Warta Ilmiah Populer Komunikasi Dalam Pembangunan. Jakarta: LIPI.

Wenerda, Indah. (2015). Politik Ekonomi Vincent Mosco oleh Media Online Entertainment Kapanlagi.com ${ }^{T M}$. ISSN: 23389176 Channel, Vol. 3, No.1, April 2015, hal 1-14. Diakses dari : http://journal.uad.ac.id/index.php/CHANNEL/article/download/2417/1491

Yin, Robert K. (2014).Studi Kasus Desain \& Metode. Jakarta: Rajawali Pers.

Yovita, Bernadetta. (2005). Ekonomi Politik Media Penyiaran (Televisi) : Komodifikasi Tayangan Kriminalitas TKP TV 7. Tesis Mahasiswa Universitas Indonesia kode panggil T22181.

\section{BIODATA}

Penulis bernama Zera Edenzwo Subandi, perempuan, lahir di Jakarta 12 Februari 1993. Ayah Penulis bernama Siauw Subandi dan Ibu Penulis bernama Sri Takwaeni. Penulis merupakan anak pertama dari tiga bersaudara. Penulis memiliki dua Adik laki-laki bernama Ega Santaka Subandi dan Willy Harfalas Subandi. Penulis merupakan lulusan sarjana dan pascasarjana Universitas Bunda Mulia, dengan mengambil studi linier untuk memperdalam bidang Ilmu Komunikasi. Penulis memulai bisnis kecil-kecilan sejak lulus sarjana, kemudian Penulis lulus pascasarjana pada usia 25 tahun dan mulai bekerja sebagai dosen Ilmu Komunikasi di Universitas Bunda Mulia pada semester ganjil tahun 2018. Kecintaan Penulis pada dunia pendidikan memberikan 
motivasi untuk berbagi benih yang sudah didapat oleh Penulis dan menggarapnya bersama, baik dengan rekan kerja dan/atau pelajar/mahasiswa. Lumbar Scoliosis dan HNP yang diderita Penulis tidak akan menghalangi semangat, karena Penulis percaya segala sesuatu yang terjadi di dalam hidup adalah seizin dan campur tangan Tuhan yang Maha Esa. 